\title{
EVALUASI TERHADAP PROGRAM FRANCHISE STUDI KASUS ALFAMART DAN INDOMARET
}

\author{
Maryadi *)
}

\begin{abstract}
Indonesia, system business by francise start to expand since year 1970 an. At the moment have a lot of foreign Franchise is which step into the Indonesia, good in commerce of goods of mupun service. This article is made by on the basis of progressively expand it effort using system Franchise, specially at effort service retail. Type Franchie we to present in this article is unit Franchising, what showing at gift of rights of took of grocery and also retailer. In this article is we will compare the franchise pursuant to terori as well as franchise pursuant to existing fact. We also compare between 2 company developing its effort by franchise that is Indomaret and Alfamart. In this article will be studied by congeniality from franchise itself and also side and conditions in opening effort by Franchise system.
\end{abstract}

Kata Kunci : Franchise, Retail, Unit Pranchising, Indomaret, Alfamart.

\section{PENDAHULUAN}

\section{A. Latar Belakang}

Franchise dipopulerkan di Negara Amerika Serika tahun 60-70 an, dimana franchise sendiri bermakna kebebasan (freedom)

Pertumbuhan Francise berawal dari masuknya waralaba asisten pada tahun 8090an dengan berdirinya kfc, Swensen dan Shakey Pisa yang kemudian diikuti oleh Burger King dan Seven Eleven. Perusahaan waralaba local pun mulai bertumbuhan pada masa itu, salah satunya adalah yang termasuk pelopor waralaba local yaitu Es Teler 77.

Pada tahun 1990, melihat partumbuhan ekonomi Indonesia yang semakin membaik, politik yang stabil dan keamanan yang terjamin, para investor dari luar negeri mulai melirik Indonesia dan di sini, francise asing mulai booming di pasar Indonesia. Dan pada tahun ini pulalah berdiri Asosiasi Francise Indonesia (AFI) sebagai wadah yang menaungi pewaralaba dan terwaralaba.
Pada tahun 1992, di Indonesia terdapat 29 francise yang berasal dari luar negeri dan 6 francise local, dan secara keseluruhan, di Indonesia tersebar sekitar 300 outlet. Pada tahun 1997, jumlah franchisor meningkat 256 franchise, di mana terdapat 235 franchise internasional dan 30 franchise lokal. Dan jumlah keseluruhan outlet adalah 2000. Pada tahun 1997, terjadi krisis moneter di Indonesia. Pada saat ini, diikuti oleh krisis ekonomi dan politik di Indonesia pada tahun 1998 yang mengakibatkan jatuhnya industri franchise di Indonesia. Banyak franchisor asing yang meninggalkan Indonesia dan hamper sekitar 500 outlet yang tutup oleh karena kondisi yang tidak mendukung ini. Pada saat ini jumlah franchise dari luar negeri yang beroperasi di Indonesia menurun dari 230 hingga 170-180 franchise. Tetapi justru pada saat ini, franchise local mulai memadati pasar franchise Indonesia dari 30 meningkat hingga 85 merek produk yang berkembang. 
Tabel 1.1 Evolusi Perkembangan Jumlah Franchise di Indonesia

\begin{tabular}{c|c|c|c|c|c|c|c|c}
\hline Tahun & $\mathbf{1 9 9 2}$ & $\mathbf{1 9 9 5}$ & $\mathbf{1 9 9 6}$ & $\mathbf{1 9 9 7}$ & $\mathbf{2 0 0 0}$ & $\mathbf{2 0 0 1}$ & $\mathbf{2 0 0 5}$ & $\mathbf{2 0 0 6}$ \\
\hline Asing & 29 & 117 & 210 & 235 & 222 & 230 & 237 & 220 \\
Lokal & 6 & 15 & 20 & 30 & 39 & 42 & 129 & 230 \\
\hline Total & 35 & 210 & 230 & 165 & 261 & 272 & 366 & 450 \\
\hline
\end{tabular}

Sumber : Direktori Franchise Indonesia Edisi 3, 2007

Hingga saat ini, frachise local berkembang hingga 360 merek produk, dimana terdapat 9000 outlet, baik sebagai franchise ataupun company owned.

Menurut Sugiyanto Wibawa, kunsultan retail marketing, terdapat 2 faktor yang mendorong para investor dalam berinvestasi di dunia franchising adalah :

Pertama, jumlah mall dan retail space yang meningkat dari $75.900 \mathrm{~m}^{2}$ menjadi 1.78 jutam $^{2}$ di tahun 2004 ( sumber : Sugiyana Wibawa, Bisnis Indonesia, Senin 27 Desember 2004) dan 2.82 juta $\mathrm{m}^{2}$ di tahun 2006 (sumber : PT. Procon Indah, Bisnis Indonesia, Senin 27 Des 2004). Agen property mempromosikan space di mall sebagai salah satu investasi yang menguntungkan.

Kedua, tariff/bunga deposito yang perlahan-lahan menurun. Hal ini mendorong pada investor untuk melihat kesempatan investasi lainnya yang lebih prospektif dan menguntungkan serta dengan resiko yang lebih kecil.

Bisnis waralaba kini telah menjamur di Indonesia. Perkembangannya membantu pelaku usaha dalam memulai suatu usaha sendiri dengan tingkat kegagalan yang rendah.

Meski bisnis waralaba yang ditawarkan semakin beragam, namun untuk menjatuhkan pilihan terhadap bisnis waralaba secara tepat, terkadang mengalami kesulitan. Padahal pilihan awal akan sangat menentukan. Ada hal mendasar dalam menentukan pilihan. Paling tidan bidang usahanya stabil dan berprospek serta track record pewaralaba (franchisor) baik dan berpengalaman.

Sebagai srategi ekspansi yang melibatkan modal pihak lain, bisnis waralaba mau tidak mau harus transparan dan konsepnya saling menguntungkan serta saling percaya di antara pewaralaba dengan terwaralaba (franchisee). Minimal selama 5 tahun bisnis waralaba tersebut mampu membuktikan sebagai perusahaan sehat, yang didukung oleh sistem dan format bisnis yang telah teruji.

Bidang usaha yang relative stabil adalah bisnis ritel. Di Indonesia bisnis ini terus berkembang seirama dengan kebutuhan pokok dan kebutuhan sehari-hari adalah minimarket. Indomaret yang tetap konsisten berkecimpung di bidang minimarket (local) dikelola secara professional dan dipersiapkan memasuki era globalisasi.

\section{B. Rumusan Masalah}

Berdasarkan latar belakang masalah diatas, maka perumusan masalahnya adalah:

1. Bagaimana perkembangan bisnis waralaba di Indonesia

2. Bagaimana cara untuk memulai suatu usaha waralaba

3. Perbedaan dari waralaba dalam bisnis retail Indomart dan Alfamart.

\section{Tujuan Pembahasan}

1. Dari sisi penulis kami ingin dapat lebih memahami tentang seluk beluk franchise itu sendiri dan bagaimana persaingan di antara 
franchisor khususnya dalam bidang retail.

2. Membantu pembaca untuk lebih memahami mengenai bisnis franchise dan dapat membantu juga para pembaca yang ingin menginvestasikan uangnya dalam usaha berbentuk franchise

3. Membantu pengusaha untuk dapat bersaing dengan sehat dalam membantu pengusaha yang ingin mengembangkan usahanya melalui bentuk usaha franchise.

\section{PEMBAHASAN}

\section{Franchise Berdasarkan Teori}

Menurut (sumber: International Franchise Association www.Franchise.org), Franchise atau waralaba pada hakekatnya memiliki 3 elemen berikut: merek, sistem bisnis dan biaya (Fees).

a. Merek

Dalam setiap perjanjian Waralaba, san Pewaralaba (Franchisor) selaku pemilik dari Sistem Waralabanya memberikan lisensi kepada Terwaralaba (Franchisee) untuk dapat menggunakan Merek Dagang/Jasa dan logo yang dimiliki oleh Pewaralaba.

b. Sistem Bisnis

Keberhasilan dari suatu organisasi Waralaba tergantung dari penerapan Sistem/Metode bisnis yang sama antara Pewaralaba dan Terwaralaba. Sistem bisnis tersebut berupa pedoman yang mencakup standarisasi produk, metode untuk mempersiapkan atau mengolah produk atau makanan, atau metode jasa, standar rupa dari fasilitas bisnis, standar periklanan, sistem reservasi, sistem akuntansi, control persediaan dan kebijakan dagang, dll.

c. Biaya (Fees)

Dalam setiap format bisnis Waralaba, sang Pewaralaba baik secara langsung atau tidak langsung menarik pembayaran dari Terwaralaba atas penggunaan merek dan atas partisipasi dalam sistem Waralaba yang dijalankan. Biaya biasanya terdiri atas Biaya Awal, Biaya Royalti, Biaya Jasa, Biaya Lisensi dan atau Biaya Pemasaran bersama. Biaya lainnya juga dapat berupa biaya atas jasa yang diberikan kepada Terwaralaba (misalnya biaya manajemen).

\section{Karakteristik Lain Dari Waralaba}

Pihak-pihak yang terkait dalam Waralaba sifatnya berdiri sendiri. Terwaralaba berada dalam posisi independen terhadap Pewaralaba berhak atas laba dari usaha yang dijalankannya, bertanggung jawab atas bebanbeban usaha waralabanya sendiri (missalnya : pajak dan gaji pegawai). Di luar itu, terwaralaba terikat pada aturan dan perjanjian dengan Pewaralaba sesuai dengan kontrak yang disepakati bersama.

\section{Ragam Tipe Waralaba}

Menurut International Franchise Association, secara umum terdapat beberapa bentuk format bisnis waralaba:

a. Unit Franchising

Bentuk waralaba ini adalah yang paling umum. Dalam unit franchise, pewaralaba memberikan hak kepada terwaralaba untuk menjalankan sejumlah satu (single) bisnis waralabanya dalam lokasi/ daerah yang telah ditentukan. Ada 2 pihak yang berkepentingan dalam 
bentuk ini, yaitu Perawaralaba dan terwaralaba

b. Area Development Franchising Dalam area development franchising, pewaralaba memberikan hak kepada terwaralaba (disebut area developer) suatu daerah tertentu yang harus dikembangkan. Terwaralaba tersebut memiliki hak dan kewajiban untuk membuka dan mengoperasikan sendiri sejumlah waralaba tertentu sesuai dengan jadwal rencana pengembangan yang telah ditetapkan sebelumnya. Biasanya, jika target jadwal rencana pengembangan waralaba yang bersangkutan tidak tercapai, pewaralaba akan memutuskan kontrak perjanjian pengembangan waralaba pada daerah tersebut. Walau begitu, unit waralaba yang berdiri tetap dapat dioperasikan oleh terwaralaba. Ada 2 yang berkepentingan dalam bentuk ini yaitu Pewaralaba dan terwaralaba.

c. Subfranchising

Subfranchising, kadang disebut juga franchising sifatnya mirip dengan area development franchising, hanya saja bentuk waralaba ini melibatkan 3 pihak. Perbedaannya adalah, pada bentuk waralaba ini melibatkan 3 pihak. Perbedaanya adalah, pada bentuk waralaba ini franchisee memiliki pilihan antara membuka sendiri unit waralabanya atau kembali unit waralaba (sub franchising) kepada pihak lain (ke-3), selama tujuan pengembangan waralaba dalam suatu daerah dapat tercapai. Bentuk kesepakatan ini umum digunakan oleh sistem waralaba internasional (terutama pewaralaba Amerika
Serikat), biasanya disebut dengan "master franchise".

d. Conversion affiliation franchising Bentuk waralaba ini terjadi jika seorang pemilik dari suatu bisnis yang telah berjalan ingin berafiliasi dengan suatu jaringan waralaba yang telah terkenal. Tujuannya adalah agar bisnis tersebut dapat memanfaatkan keuntungan dari merek terkenal dan juga sistem operasi dari jejaring waralaba yang bersangkutan. Dalam affiliation franchising ini, terwaralaba biasanya diperbolehkan untuk tetap menggunakan merek lama yang telah mereka miliki diikuti dengan merek terkenal dari sang pewaralaba. Bentuk waralaba ini banyak diterapkan di industri perhotelan.

e. Nontraditional Franchising

Pada bentuk waralaba ini, pewaralaba menjual waralabanya untuk ditempatkan pada tempat-tempat tertentu yang khusus. Misalkan, suatu unit waralaba yang dijual didalam lokasi bisnis (mis:ritel) milik orang lain. Dalam hal ini pewaralaba membuat 2 perjanjian, yaitu perjanjian dengan terwaralaba dan perjanjian dengan pemilik bisnis.

\section{Dasar Hukum Franchise}

a. Perjanjian sebagai dasar hokum KUH Perdata 1338 (1), 1233 s/d 1456 KUH Perdata, para pihak bebas melakukan apapun sepanjang tidak bertentangan dengan hokum yang berlaku, kebiasaan, kesopanan atau hal-hal lain yang behubungan dengan ketertiban umum, juga tentang syarat-sayarat sahnya perjanjian dan sebagainya. 
b. Hukum keagenan sebagai dasar hokum, KUH Dagang (Makelar dan Komisioner), ketentuanketentuan yang bersifat administrative seperti berbagai ketentuan dari Departemen Perindustrian, Perdagangan dan sebagainya. Seringkali di tentukan dengan tegas dalam kontrak franchise bahwa di antara pihak franchisor dengan franchisee tidak ada suatu hubungan keagenan.

c. Undang-undang Merek, Paten dan Hak Cipta sebagai dasar hokum, berhubung ikut terlibatnya merek dagang dan logo milik pihak franchisor dalam suatu bisnis franchise, apalagi dimungkinkan adanya suatu penemuan baru oleh pihak franchisor, penemuan dimana dapat dipatenkan. UU No. 19 (1982) Paten, UU No. 7 (1987) Hak Cipta.

d. UU Penanaman Modal Asing sebagai dasar hukum, apabila pihak franchisor tersebut maka sebaiknya dikonsultasi dahulu kepada ahli hokum penanaman modal asing tentang berbagai kemungkinan dan alternative yang mungkin diambil dan yang paling menguntungkannya. Franchise justru dipilih untuk mengelak dari larangan-larangan tertentu bagi suatu perusahaan asing ketika hendak beroperasi lewat direct investment.

Peraturan lain sebagai dasar hokum franchisee :

a. Ketentuan hokum administrative, seperti mengenai perizinan usaha, Pendirian perseroan terbatas, dan lain-lain peraturan administrasi yang umumnya dikeluarkan oleh (Sumber Departemen Perdagangan Kepmen
Perdagangan No. 376/Kp/XI/1983) tentang kegiatan perdangangan.

b. Ketentuan ketenagakerjaan

c. Hukum Perusahaan (UU PT. No. 1 (1995)

d. Hukum pajak adalah pajak ganda, pajak penghasilan, pajak pertambahan nilai, pajak withholding atas royalty dan pajak penghasilan atas tenaga kerja asing.

e. Hukum persaingan

f. Hukum industri bidang tertentu misalnya aturan tentang standar mutu, kebersihan dan aturan lain yang bertujuan melindungi konsumen, atau bahkan UU pangan sendiri.

g. Hukum tentang kepemilikan hak guna bangunan, hak milik.

h. Hukum tentang pertukaran mata uang RI menganut rezim devisa bebas, maka tidak ada larangan maupun batasan terhadap keluar masuknya valuta asing dari/ke Indonesia.

i. Hukum tentang rencana tata ruang, apakah wilayah tersebut memenuhi syarat.

j. Hukum tentang pengawasan ekspor/impor misalnya dalam hal pengambilan keputusan apakah barang-barang tertentu mesti dibawa dari Negara pihak franchisor atau cukup diambil saja dari Negara pihak franchisee.

k. Hukum tentang bea cukai apakah lebih menguntungkan barangbarang tertentu dipasok dari luar negeri atau cukup menghandalkan produk lokal semata.

\section{Indomaret}

Tahun 1997 Indomaret melakukan pola kemitraan (waralaba) dengan mem- 
buka peluang bagi masyarakat luas untuk turut serta memiliki dan mengelola sendiri gerai Indomaret. Pola waralaba ini ditawarkan setelah Indomaret terbukti sehat dengan memiliki lebih dari 700 gerai, yang didukung oleh sistem dan format bisnis yang baik.

Pengalaman panjang yang telah teruji itu mendapat sambutan positif masyarakat, terlihat dari meningkat tajamnya jumlah gerai waralaba Indomaret, dari dua gerai pada tahun 1997 menjadi 785 gerai pada Desember 2006. Program waralaba Indomaret yang tidak rumit terbukti dapat diterima masyarakat. Bahkan sinergi pewaralaba (Indomaret) dan terwaralaba (masyarakat) ini merupakan salah satu keunggulan domestic dalam memasuki era globalisasi.

a. Keuntungan Waralaba Indomaret

1. Transformasi Pengetahuan

Bergabung dengan Indomaret, akan banyak diperoleh pengetahuan bisnis toko modern dan sekaligus menempatkan anda sebagai pelaku bisnis

2. Potensi Pasar

Bantuan survey lokasi dari Indomaret akan memperkaya wawasan mengenai potensi dan strategi tidaknya suatu lokasi

3. Tidak Full Time

Dukungan sistem operasional toko yang terintegrasi, membuat para investor tidak perlu terlibat secara full time dalam operasional toko ataupun meninggalkan pekerjaan sebelumnya.

4. Peluang Berkembang Investor dapat memiliki lebih dari satu unit toko dengan tingkat kesibukan yang sama dan dapat diatur.

5. Minimalisasi Risiko

Perencanaan matang, mulai survey lokasi sampai dengan pembukaan toko, kecepatan distribusi dan kelengkapan barang dagangan, serta dukungan manajemen Toko yang Solid akan membantu Investor dalam menekan risiko kerugian.

b. Menjadi Terwaralaba Indomaret

Jika anda memutuskan untuk membeli hak waralaba Indomaret, langkah awal yang harus dipenuhi adalah:

1. Warga Negara Indonesia

2. Menyediakan ruang usaha ukuran 120-150 $\mathrm{M}^{2}$ (milik sendiri/sewa)

3. Memiliki NPWP dan PKP, serta kelengkapan perijinan lainnya

4. Investasi peralatan toko dan biaya waralaba

Indomaret akan membantu anda dalam menyiapkan pengelolaan toko dalam hal :

1. Survey kelayakan tempat usaha dan bantuan mencari lokasi

2. Perencanaan anggaran biaya

3. Studi kelayakan Investasi

4. Tata ruang dan perencanaan toko

5. Pengurusan ijin usaha dan NPWP

6. Renovasi ruang usaha

7. Pembelian peralatan toko

8. Seleksi dan pelatihan karyawan

9. Standard kerja dan sistem penggajian karyawan

10. Paket sistem operasional toko dan administrasi keuangan

11. Seleksi dan kredit barang dagangan tanpa bunga dan tanpa jaminan

12. Program promosi penjualan

c. Pola Waralaba

Ada dua pola kerja sama waralaba :

1. Tidak memiliki tempat usaha Jika anda tidak memiliki tempat usaha, indomaret menawarkan 2 opsi kerja sama.

a) Usulan lokasi took baru

Indomaret menawarkan lokasi yang telah disurvey disertai perencanaan matang, mulai dari 
desain layout toko, estimasi investasi, pendapatan, pengeluaran dan payback period.

b) Take over kepemilikan Indomaret menawarkan toko milik sendiri, yang sudah teruji dan menguntungkan. Sistem ini relative lebih safe namun nilai investasinya lebih tinggi dibanding dengan membuka toko baru karena ada nilai goodwill, sebagai pengganti biaya pengembangan toko, sejak dibuka hingga mencapai kondisi mapan.

2. Memiliki tempat usaha Apabila anda telah memiliki lokasi usaha, indomaret menawarkan kerja sama sebagai berikut :

a) Ruang usaha/rumah/tanah

Prosedur kerjanya sama dengan "Usulan lokasi toko baru".
Indomaret terlebih dulu melakukan survey kelayakan lokasi yang anda usulkan, mulai dari potensi wilayah, peruntukan bangunan dan perijinan, perencanaan layout toko sampai dengan estimasi payback periodnya. Jika semua dinilai layak, kerja sama dapat dilakukan. Akan tetapi jika tidak atau ada kendala lain, Indomaret akan menyerahkan untuk mencari lokasi yang lain.

b) Minimarket existing

Bila anda memiliki toko yang berkembang dan ingin mengembangkannya, dapat bergabung dengan Indomaret. Prosedur standarnya sama, mulai dari survey kelayakan lokasi sampai dengan estimasi payback period.

Tabel 1

Perhitungan Laba dari Si Murah dan Hemat (Indomaret) Ilustrasi Hitungan Laba Bagi Waralaba Indomaret

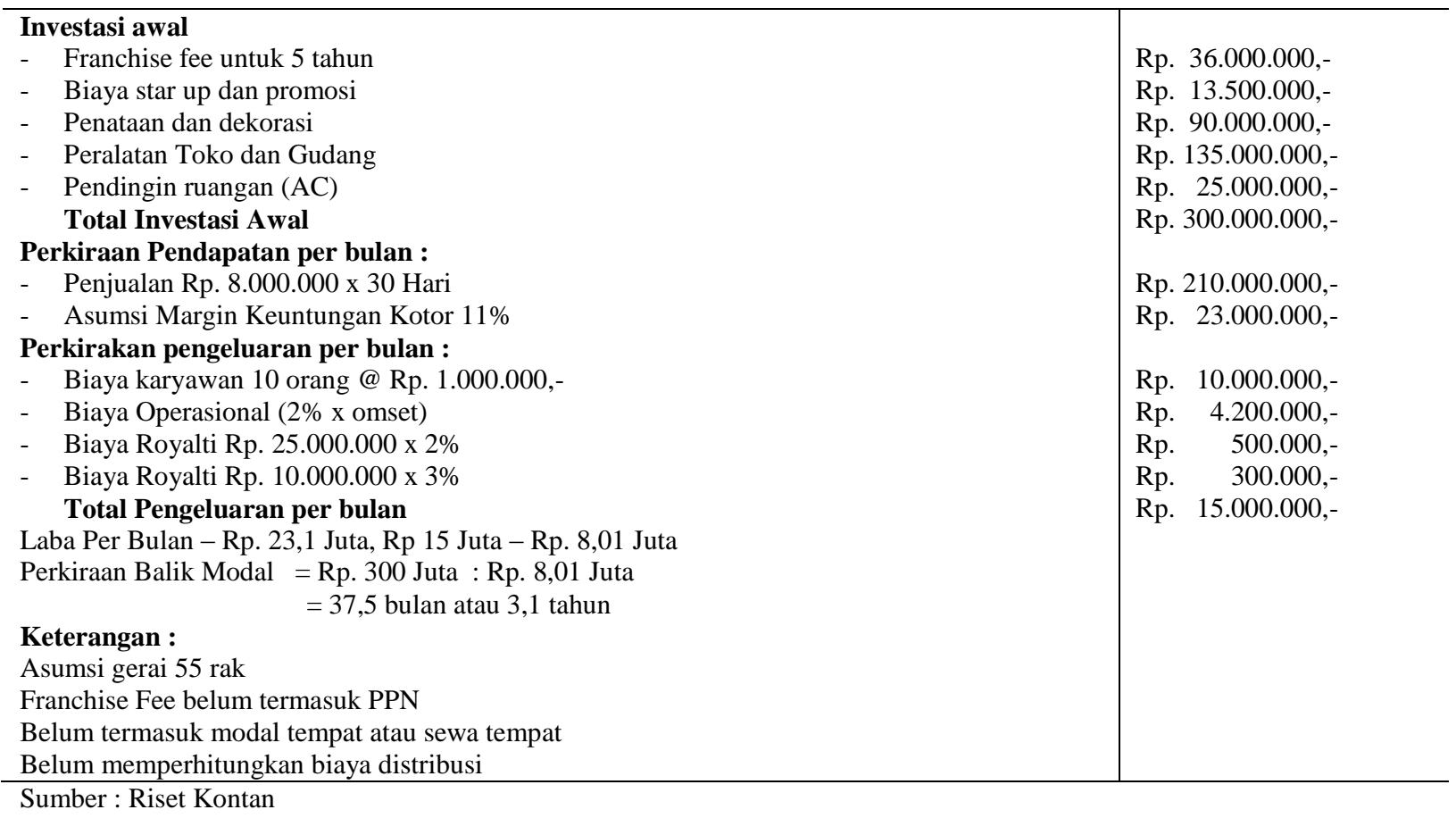




\section{Alfamart}

Siapa yang tidak mengenal Alfamart? Lewat slogamnya yang berbunyi 'belanja puas harga pas' Alfamart sangat familier di telinga. Selain karena jaringan usahanya yang telah menggurita juga karena Alfamart bias dibilang adalah satusatunya usaha waralaba yang paling giat dan serius dalam melakukan promosi dalam upaya mendekatkan diri ke pelanggan. Alfamart adalah satu-satunya bisnis waralaba yang gencar melakukan strategi komunikasi demi memperkuat brand awareness dan loyalitas pelanggan.

Alfamart yang mulai berdiri pada 18 Oktober 1999 dengan outlet pertama yang beroperasi di Jl. Beringin -Tangerang. Sejak difranchisekan 5 tahun lau Alfamart terus berkembang pesat hingga saat ini. Total kini Alfamart telah memiliki outlet lebih 2.000 buah yang tersebar di pulau Jawa dan Lampung, dengan didukung oleh 10 Distribution Centre (DC). Menariknya, dari keseluruhan outlet tersebut 35\%-nya dioperasikan dengan sistem franchise.

Alfamart yang mencetak rekor MURI sebagai minimarket pertama di Indonesia yang memperolej ISO 9001 ini mematok fee royalty sekitar Rp. 45 juta dengan other income Rp. 6 juta per bulan ( 6 x 60 bulan $=$ Rp. 360 juta).

\section{Keuntungan Bermitra dengan Alfamart}

1. Survey lokasi detail dan perencanaan desain took

2. Target pasar jelas

3. Seleksi produk berkualitas dengan standar Alfamart
4. Supply barang dagangan $100 \%$ dari Alfamart

5. Bantuan seleksi dan pelatihan karyawan oleh Alfamart

6. Paket sistem dan administrasi keuangan took Alfamart

7. Promosi dan pembukaan took

8. Panduan, bimbingan operasional, supervise dan konsultasi selama 5 tahun

9. Tergabung bersama jaringan Alfamart.

\section{Syarat Menjadi Terwaralaba}

1. Perorangan / Badan Usaha (Koperasi, CV, PT, dll)

2. Warga Negara Indonesia

3. Sudah atau akan mempunyai lokasi tempat usaha dengan luas $80 \mathrm{~m}^{2}$ (diluar gudang dan tempat tinggal karyawan)

4. Memenuhi persyaratan perijinan

5. Mempunyai area yang cukup

6. Bersedia mengikuti sistem dan prosedur yang berlaku di Alfamart

\section{Royalti Fee}

Tabel 2

Perhitungan Royalti Fee di hitung Secara Progresif

\begin{tabular}{l|c}
\hline \multicolumn{1}{c|}{ Penjualan Bersih } & Persentase \\
\hline Rp. 0 s/d Rp. 75.000.000. & $0 \%$ \\
Rp. 75.000.000. s/d Rp. 100.000.000. & $2 \%$ \\
Rp. 100.000.000. s/d Rp. 150.000.000. & $2.5 \%$ \\
> Rp. 150.000.000. & $3 \%$ \\
\hline
\end{tabular}

\section{Perkiraan Biaya Investasi Awal}

Sebagai gambaran mungkin bias dijelaskan melalui ilustrasi berikut ini

Tabel 3

Perkiraan Biaya Investasi Awal

\begin{tabular}{|c|c|c|c|c|}
\hline Tipe Toko & Item & Luas Toko & Invest/Sewa* & Total \\
\hline 36 Rak & 3.000 & $90 \mathrm{~m}^{2}$ & Rp. 425 juta \\
\hline 45 Rak & 3.500 & $90-150 \mathrm{~m}^{2}$ & 330 juta / 125 juta 150 juta & Rp. 480 juta \\
\hline 54 Rak & 4.000 & $>150 \mathrm{~m}^{2}$ & 380 juta / 175 juta & Rp. 555 Juta \\
\hline
\end{tabular}




\section{Contoh Perincian Perkiraan Biaya Investasi}

Tabel 4

Contoh Perincian Biaya Investasi

\begin{tabular}{|c|c|}
\hline Rincian & Biaya \\
\hline 1. $\quad$ Franchise Fee (biaya waralaba) selama 5 tahun & Rp. $45.000 .000,-$ \\
\hline 2. Renovasi sipil dan listrik (mechanical dan electrical) & Rp. 120.000.000,- \\
\hline Perijinan & Rp. $15.000 .000,-$ \\
\hline 4. Perlengkapan took dan AC (Air Conditioner) & Rp. $70.000 .000,-$ \\
\hline 5. Komputerisasi & Rp. $\quad 20.000 .000,-$ \\
\hline 6. Promosi dan Pembukaan Toko & Rp. 20.000.000,- \\
\hline 7. Shop sign dan Single pole & Rp. $\quad 10.000 .000,-$ \\
\hline & Rp. 300.000.000,- \\
\hline
\end{tabular}

\section{KESIMPULAN}

Perkembangan usaha waralaba di

\section{DAFTAR PUSTAKA}

Indonesia sangat berkembang pesat. Usaha Wawalaba banyak diminati karena dianggap dapat menguntungkan

Departemen Perdagangan, Kepmen No.

dibandingkan dengan membuka usaha sendiri

Salah satu bisnis waralaba yang sangat diminati adalah bisnis retail, seperti INDOARET dan ALFAMART. Dengan modal yang tidak begitu besar dan kemudahan dalam berbisnis, membuat bisnis ini semakin diminati. Selain itu, barang yang dijual adalah barang-barang kebutuhan dasar, sehingga dapat dipastikan usaha ini dapat tetap bertahan dalam kondisi apapun.

376/KP/XI/1983

Direktori Franchise Indonesia Edisi 3, 2007

http:www.waralaba.com/franchisebasics.ph p? page- mode $=$ detail $\& i d=4$

International Franchise Association (www.Franchise.org).

PT. Procon Indah, Bisnis Indonesia, Senin 27 Desember 2004 Riset Kontan

Sugiyana Wibawa, Bisnis Indonesia, Senin 27 Desember 2004

*) Penulis adalah Dosen Tetap Yayasan Pendidikan Nobel Indonsia Makassar 